\title{
PENGARUH ALASAN PEMBERHENTIAN TERHADAP SEMANGAT KERJA KARYAWAN PT. JAKARTA PONSEL XXI PAMEKASAN
}

\author{
Achmarul Fajar ${ }^{(1)}$ \\ Mohammad Amir Furqon ${ }^{(2)}$ \\ Furqon@unira.ac.id \\ Akhmad Faishol Zaidani ${ }^{(3)}$ \\ Universitas Madura
}

\begin{abstract}
ABSTRAK
Latar belakang masalah dari penelitian ini adalah ketika peneliti melakukan survei pendahuluan dengan menjadi pembeli dan sambil mengamati aktivitas dan kegiatan di PT. Jakarta Ponsel XXI Pamekasan, ada beberapa karyawan terlihat tidak bersemangat dalam bekerja seperti adanya karyawan yang cuman duduk sambil main handphone meskipun ada pembeli datang, karyawan yang hanya menawarkan barang saja tanpa memberikan informasi lengkap tentang produk yang dijual di PT. Jakarta Ponsel tersebut. Tujuan penelitian ini adalah Pertama untuk mengetahui pengaruh secara bersama-sama alasan pemberhentian yang terdiri dari keinginan perusahaan dan keinginan karyawan terhadap semangat kerja karyawan PT. Jakarta Ponsel XXI Pamekasan. Serta untuk mengetahui variabel yang paling dominan mempengaruhi semangat kerja karyawan PT. Jakarta Ponsel XXI Pamekasan.

Salah satu teori yang mendasari analisis penelitian ini adalah Teori Malayu Hasibuan yang memberikan definisi pemberhentian adalah pemutusan hubungan kerja seseorang karyawan dengan suatu organisasi perusahaan.

Pengumpulan data pada penelitian ini adalah menggunakan wawancara dan menyebarkan angket, sebanyak 27 angket pada responden. Dari uji validitas sebanyak 11 item, yang terdiri 3 item tidak valid dan 8 item tersebut valid sedangkan pada uji reliabilitas terbukti semua instrument data yang digunakan pada penelitian ini adalah reliabel atau handal.

Alalisis linier regresi berganda dihitung dengan metode SPSS ditemukan persamaannya yaitu $Y=0,249+1,033 X_{1}+0,057 X_{2}$

Dari persamaan tersebut, adanya kedua faktor memberikan kontribusi positif atau bertambah terhadap faktor mempengaruhi semangat kerja karyawan PT. Jakarta Ponsel XXI Pamekasan sebesar 0,249 atau $24,9 \%$.

Pada hipotesis pertama dengan uji F, F hitung sebesar 103,908 lebih besar dari $F$ tabel 3,40 , maka hipotesis pertama tersebut benar secara simultan ada pengaruh alasan pemberhentian yang terdiri dari keinginan perusahaan dan keinginan karyawan terhadap semangat kerja karyawan PT. Jakarta Ponsel XXI Pamekasan. Pada hipotesis yang kedua dengan menggunakan uji t, terbukti keinginan perusahaan yang paling dominan mempengaruhi semangat kerja karyawan PT. Jakarta Ponsel XXI Pamekasan sebesar 12,23 dan dinyatakan hipotesis yang pertama diterima.
\end{abstract}

Keyword: Keinginan Perusahaan, Keinginan Karyawan Dan Semangat Kerja Karyawan.

\section{PENDAHULUAN}

\subsection{Latar Belakang Masalah}

Perusahaan merupakan suatu unit kegiatan produksi yang mengelola sumber-sumber daya yang ada mulai dari sumber daya alam hingga sampai sumber daya manusia itu sendri sehingga perlu pengelolaan yang optimal agar dapat dicapai tujuan yang diharapkan.

PT. Jakarta Ponsel XXI Pamekasan merupakan salah satu toko handphone segala merk yang terletak di Jl. Trunojoyo No.837 Pamekasan. 
Perkembangan PT. Jakarta Ponsel XXI Pamekasan semakin meningkat, hal ini dapat dilihat dari aktivitas atau transaksi masyarakat mendatangi dan membeli produk handphone di PT. Jakarta Ponsel XXI Pamekasan yang semakin meningkat. Pengelolaan manajemen yang baik merupakan faktor penting terhadap semua karyawan perusahaan.

Sering kita menemui karyawan yang berhenti hanya gara-gara kecewa dengan perusahaannya atau diberhentikan oleh perusahaan itu sendiri. Perusahaan memperlakukan karyawannya hanya sebagai pion ataupun sapi perah. Banyak perusahaan yang tidak melihat karyawan sebagai manusia secara utuh yang mempunyai segi emosi, segi kesehatan, segi ekonomi, segi pengakuan diri, dll.

Tidak hanya karyawan yang sering kecewa namun terkadang dapat berbanding terbalik, perusahaan juga bisa kecewa terhadap karyawannya karena karyawan yang bekerja untuk perusahaan tidak sesuai dengan keinginan perusahaan padahal perusahaan telah memberikan apa yang menjadi Hak karyawan.

Semangat kerja karyawan dalam bekerja menjadi salah satu faktor kemajuan perusahaan, karyawan memiliki kegairahan dan keinginan yang timbul dari dalam diri karyawan untuk bekerja dengan baik supaya perusahaan bangga terhadap karyawan.

Bisa kita lihat di perusahaan maju dan besar. Mereka menjadikan karyawan sebagai aset yang perlu dilindungi dan ditangani dengan sangat baik. Mereka memberi imbalan karyawan tidak sekedar gaji yang layak, tapi juga unsur jaminan kesehatan, perkembangan karir, kesehatan jiwa, lingkungam, sukungan positif dari manajemen, ketegasan dalam menjalankan peraturan, desain kantor yang bagus dan budaya perusahaan yang positif. Membuat karyawan semangat bekerja di perusahaan memang bukan hal yang gampang, tapi bukan hal mutlak yang tak bisa dijalankan.

Apabila karyawan sudah senang dan bahagia bekerja tanpa berpikir berhenti atau diberhentikan, Karyawan akan bersemangat dalam bekerja agar perusahaannya maju pesat.

Ketika peneliti melakukan survei pendahuluan dengan menjadi pembeli dan sambil mengamati aktivitas dan kegiatan di PT. Jakarta Ponsel XXI Pamekasan, ada beberapa karyawan terlihat tidak bersemangat dalam bekerja seperti adanya karyawan yang cuman duduk sambil main handphone meskipun ada pembeli datang, karyawan yang hanya menawarkan barang saja tanpa memberikan informasi lengkap tentang produk yang dijual di PT. Jakarta Ponsel tersebut. Apa yang terjadi belum pasti diketahui, Namun peneliti beranggapan bahwa ada beberapa permasalahan yang menjadikan karyawan tidak bersemangat bekerja diantaranya, bisa karena beban pikiran karyawan terhadap keinginan perusahaan yang menginginkan atau menargetkan sesuatu yang sulit dilakukan oleh karyawan dan jika tidak terpenuhi maka untuk bulan berikutnya akan diberhentikan bekerja dan mungkin dari keinginan karyawan itu sendiri belum dipenuhi oleh perusahaan yang membuat karyawan untuk mengundurkan diri atau berhenti dari PT. Jakarta Ponsel. Sehingga dalam hal ini tentu mempengaruhi aktivitas kerja terutama semangat kerja karyawan setiap harinya.

Buatlah karyawan semangat bekerja sehingga memberikan yang terbaik terhadap perusahaan dan perusahaan akan berpikir dan mempertimbangkan untuk memberhentikan karyawan. Dan tentu karyawan tidak akan berpikir untuk berhenti karena dengan semangat bekerja yang baik karyawan akan berpikir untuk bagaimana mencapai atau melakukan apa yang diinginkan perusahaan.

Dari uraian diatas dapat kita lihat bahwa karyawan yang bekerja pada suatu perusahaan agar harapan perusahaan dan karyawan tercapai maka diperlukan suatu prosedur pemberhentian yang baik agar semangat kerja karyawan terjaga, Sehingga Penulis tertarik untuk mengadakan penelitian yang kemudian akan 
dituangkan dalam bentuk tulisan ilmiah (penelitian) yang berjudul " Pengaruh Alasan Pemberhentian Terhadap Semangat Kerja Karyawan PT. Jakarta Ponsel XXI Pamekasan “.

\subsection{Rumusan Masalah}

Berdasarkan latar belakang di atas, maka rumusan masalah penelitian ini adalah :

1. Bagaimana pengaruh secara bersama-sama alasan pemberhentian (X) yang terdiri dari keinginan perusahaan $\left(X_{1}\right)$ dan keinginan karyawan $\left(X_{2}\right)$ terhadap semangat kerja karyawan (Y) PT. Jakarta Ponsel XXI Pamekasan?
2. Variabel manakah yang paling dominan mempengaruhi semangat kerja karyawan PT. Jakarta Ponsel XXI Pamekasan?

1.3 Batasan Masalah dan Kerangka Pemikiran

\subsubsection{Batasan Masalah}

Berdasarkan latar belakang dan rumusan masalah, maka batasan masalah penelitian ini adalah :

1. Alasan pemberhentian yang dibahas pada penelitian ini adalah alasan pemberhentian di lingkungan kerja PT. Jakarta ponsel XXI Pamekasan.

2. Responden penelitian ini adalah semua karyawan PT. Jakarta ponsel XXIPamekasan.

\subsubsection{Kerangka Pemikiran}

Gambar 1.1

Pengaruh Alasan Pemberhentian Terhadap Semangat Kerja Karyawan

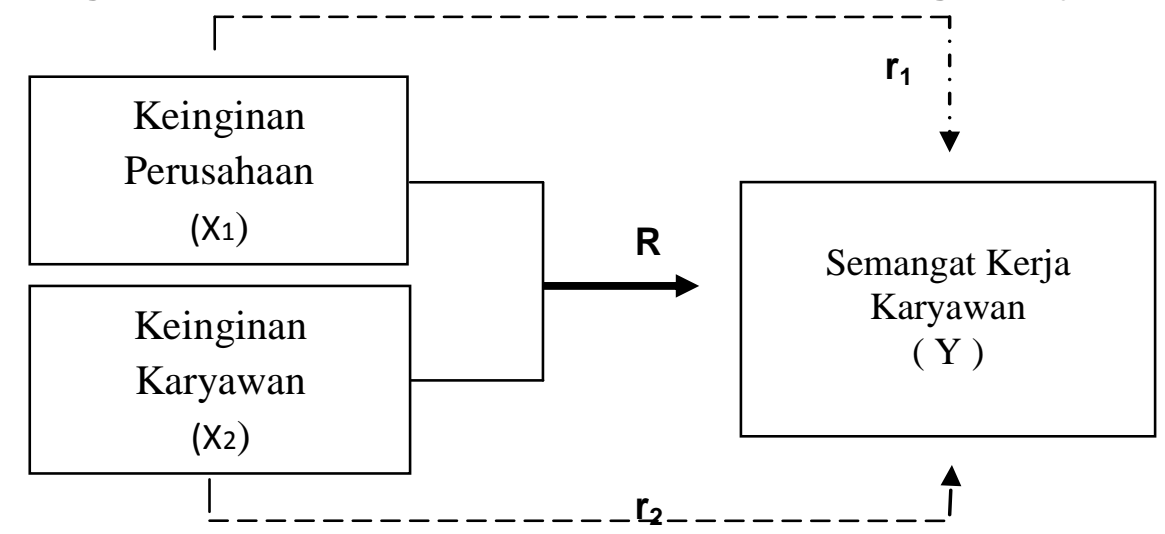

Keterangan :

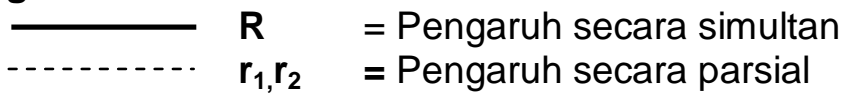

Berdasarkan bagan kerangka pemikiran gambar 1.1 menunjukkan bahwa Alasan pemberhentian $(X)$ yang terdiri dari keinginan perusahaan $\left(X_{1}\right)$ dan keinginan karyawan $\left(X_{2}\right)$ secara bersama-sama (Simultan) dengan simbol $R$, dan secara parsial dengan simbol $r_{1}$, $r_{2}$ mempengaruhi semangat kerja karyawan dengan simbol $(Y)$.

\subsection{Tujuan Penelitian}

Adapun tujuan penelitian yang hendak dicapai dalam penelitian ini adalah sebagai berikut :

1. Untuk mengetahui pengaruh secara bersama-sama alasan pemberhentian
(X) yang terdiri dari keinginan perusahaan $\left(X_{1}\right)$ dan keinginan karyawan $\left(X_{2}\right)$ terhadap semangat kerja karyawan (Y) PT. Jakarta Ponsel XXI Pamekasan.

2. Untuk mengetahui variabel manakah yang paling dominan mempengaruhi semangat kerja karyawan PT. Jakarta Ponsel XXI Pamekasan.

\subsection{Manfaat Penelitian}

Dalam penelitian ini diharapkan dapat memberikan manfaat diantaranya sebagai berikut:

1. Bagi Peneliti sebagai bahan pembelajaran dan mengetahui alasan 
pemberhentian serta dapat pula mengetahui pengaruhnya terhadap semangat kerja karyawan PT. Jakarta Ponsel XXI Pamekasan.

2. Bagi PT. Jakarta Ponsel dijadikan sebagai bahan pertimbangan bagi kemajuan perusahaan tempat peneliti mengadakan penelitian, dalam pengambilan keputusan terhadap masalah alasan pemberhentian terhadap semangat kerja karyawannya.

3. Bagi Universitas Madura Khusunya Fakultas Ekonomi Program Studi Manajemen dapat memberikan suatu hasil penelitian tentang alasan pemberhentian.

4. Bagi Peneliti Lanjutan dapat dijadikan bahan informasi kajian ilmu pengetahuan yang dapat dijadikan acuan pengembangan keilmuan yang berhubungan dengan alasan pemberhentian.

\section{TINJAUAN PUSTAKA DAN HIPOTESIS}

\subsection{Pengertian Pemberhentian}

Menurut Undang-undang No. 13 Tahun 2003 mengartikan bahwa Pemberhentian atau Pemutusan hubungan kerja adalah pengakhiran hubungan kerja karena suatu hal tertentu yang mengakibatkan berakhirnya hak dan kewajiban antar pekerja dan pengusaha.

Sedangkan menurut Hasibuan $(2013 ; 209)$ " pemberhentian adalah pemutusan hubungan kerja seseorang karyawan dengan suatu organisasi perusahaan."

\begin{tabular}{l}
\multicolumn{2}{c}{ "Pemutusan hubungan kerja } \\
(PHK) adalah suatu kondisi tidak \\
bekerjanya lagi karyawan pada suatu \\
perusahaan karena hubungan kerja \\
antara yang bersangkutan dengan \\
perusahaan terputus, atau tidak \\
diperpanjang lagi." \\
Sedarmayanti, 2007;313)
\end{tabular}

Pemutusan hubungan kerja merupakan fungsi terakhir manajer sumberdaya manusia yang dapat didefinisikan sebagai pengakhiran hubungan kerja antara pekerja dan pengusaha yang dapat disebabkan oleh berbagai macam alasan, sehingga berakhir pula hak dan kewajiban di antara mereka.

\subsection{Alasan Pemberhentian}

Menurut Hasibuan (2013;210-

211) ada beberapa alasan-alasan pemberhentian, diantaranya :

a. Keinginan Perusahaan

"Keinginan perusahaan dapat menyebabkan diberhentikannya seorang karyawan baik secara terhormat ataupun dipecat. Pemberhentian semacam ini telah diatur oleh Undang-undang No.12 Tahun 1964, seizin P4D atau P4P, serta tergantung status kepegawaian bersangkutan.

Keinginan perusahaan memberhentikan karyawan disebabkan hal-hal berikut.

1. Karyawan tidak mampu menyelesaikan tugasnya.

2. Perilaku dan disiplinnya kurang baik.

3. Melanggar peraturanperaturan dan tata tertib perusahaan.

4. Tidak dapat bekerja sama dan terjadi konflik dengan karyawan lain.

5. Melakukan tindakan amoral dalam perusahaan."

\section{b. Keinginan Karyawan}

"Pemberhentian atas keinginan karyawan sendiri dengan mengajukan permohonan untuk berhenti dari perusahaan tersebut. Permohonan hendaknya disertai alasan-alasan dan saat akan berhentinya, misalnya bulan depan. Hal ini perlu agar perusahaan dapat mencari penggantinya, supaya kegiatan perusahaan jangan sampai mandek. 
Alasan-alasan pengunduran, antara lain :

1. Pindah ketempat lain untuk mengurus orang tua,

2. Kesehatan yang kurang baik,

3. Untuk melanjutkan pendidikan, atau

4. Berwiraswasta.

Akan tetapi seringkali alasan-alasan itu hanya dibuat-buat saja oleh karyawan sedangkan alasan yang sesungguhnya adalah balas jasa terlalu rendah, mendapat pekerjaan yang lebih baik, suasana dan lingkungan pekerjaan yang kurang cocok, kesempatan promosi yang tidak ada, perlakuan yang kurang adil, dan sebagainya."

\subsubsection{Sepuluh Alasan PHK yang Dapat Digunakan oleh Perusahaan}

Ada sepuluh alasan PHK, yang dapat digunakan perusahaan untuk mem-PHK Anda dengan mengacu kepada Undang-Undang No. 13 tahun 2003.

Pertama adalah Anda melakukan kesalahan berat.

Pasal 158, ayat 1 berbunyi, "Pengusaha dapat memutuskan hubungan kerja terhadap pekerja/buruh dengan alasan pekerja/buruh telah melakukan kesalahan berat sebagai berikut:

1. melakukan penipuan, pencurian, atau penggelapan barang dan atau uang milik perusahaan;

2. memberikan keterangan palsu atau yang dipalsukan sehingga merugikan perusahaan;

3. mabuk, meminum minuman keras yang memabukkan, memakai dan/atau mengedarkan narkotika, psikotropika, dan zat adiktif lainnya di lingkungan kerja;

4. melakukan perbuatan asusila atau perjudian di lingkungan kerja;

5. menyerang, menganiaya, mengancam, atau mengintimidasi teman sekerja atau pengusaha di lingkungan kerja;

6. membujuk teman sekerja atau pengusaha untuk melakukan perbuatan yang bertentangan dengan peraturan perundang-undangan;
7. dengan ceroboh atau sengaja merusak atau membiarkan dalam keadaan bahaya barang milik perusahaan yang menimbulkan kerugian bagi perusahaan;

8. dengan ceroboh atau sengaja membiarkan teman sekerja atau pengusaha dalam keadaan bahaya di tempat kerja;

9. membongkar atau membocorkan rahasia perusahaan yang seharusnya dirahasiakan kecuali untuk kepentingan negara; atau

10. melakukan perbuatan lainnya di lingkungan perusahaan yang diancam pidana penjara 5 (lima) tahun atau lebih."

Namun, perlu Anda ketahui bahwa alasan phk berupa kesalahan berat yang dimaksud pada Pasal 158, ayat 1 harus didukung dengan bukti misalnya,

1. pekerja/buruh tertangkap tangan;

2. ada pengakuan dari pekerja/buruh yang bersangkutan; atau

3. bukti lain berupa laporan kejadian yang dibuat oleh pihak yang berwenang di perusahaan yang bersangkutan dan didukung oleh sekurang-kurangnya 2 (dua) orang saksi.

Kedua adalah Anda ditahan pihak yang berwajib karena diduga melakukan tindak pidana.

Pasal 160, ayat 1

menyebutkan, "Dalam hal pekerja/buruh ditahan pihak yang berwajib karena diduga melakukan tindak pidana bukan atas pengaduan pengusaha,..."

Ketiga adalah Anda melakukan pelanggaran ketentuan yang telah diatur dalam Perjanjian Kerja.

Pasal 161, ayat 1
menyebutkan, "Dalam hal
pekerja/buruh ran
pelanggaran ketentuan yang diatur
dalam perjanjian kerja, peraturan
perusahaan atau perjanjian kerja
bersama, pengusaha dapat
melakukan pemutusan hubungan
kerja, setalah kepada
pekerja/buruh yang bersangkutan


diberikan surat peringatan pertama, kedua, dan ketiga secara berturut-turut."

$$
\text { Bila Anda tidak }
$$

mengindahkan peraturan perusahaan dan Anda tidak mengindahkan surat peringatan yang diberikan oleh perusahaan kepada Anda- ini bisa menjadi alasan PHK untuk pekerja.

Keempat adalah Anda tidak mau bekerja pada perusahaan oleh karena terjadi perubahan status, penggabungan, peleburan, atau perubahan kepemilikan perusahaan.

Pasal 163, ayat 1 menyebutkan, "Pengusaha dapat melakukan pemutusan hubungan kerja terhadap pekerja/buruh dalam hal terjadi peru-bahan status, penggabungan, peleburan, atau perubahan kepemilikan perusahaan dan pekerja/buruh tidak bersedia melanjutkan hubungan kerja.........."

Kelima adalah perusahaan tidak bersedia menerima Anda sebagai karyawan di perusahaan oleh karena terjadi perubahan status, penggabungan, peleburan, atau perubahan kepemilikan perusahaan.

Pasal 163, ayat 2 menyebutkan, "Pengusaha dapat melakukan pemutusan hubungan kerja terhadap pekerja/buruh karena perubahan status, penggabungan, atau peleburan perusahaan, dan pengusaha tidak bersedia menerima pekerja/buruh di perusahaannya, ....."

Keenam adalah perusahaan tutup akibat mengalami kerugian terus menerus selama dua dua (2 tahun).

Pasal 164, ayat 1 menyebutkan, "Pengusaha dapat melakukan pemutusan hubungan kerja terhadap pekerja/buruh karena perusahaan tutup yang disebabkan perusahaan mengalami kerugian secara terus menerus selama 2 (dua) tahun, atau keadaan memaksa (force majeur)...."

Kerugian perusahaan yang dimaksud harus dibuktikan dengan laporan keuangan 2 (dua) tahun terakhir yang telah diaudit oleh akuntan publik.

Ketujuh adalah perusahaan melakukan efisiensi.

Ini merupakan alasan phk yang sering digunakan. Pasal 164, ayat 3 menyebutkan, "Pengusaha dapat melakukan pemutusan hubungan kerja terhadap pekerja/buruh karena perusahaan tutup bukan karena mengalami kerugian 2 (dua) tahun berturutturut atau bukan karena keadaan memaksa (force majeur) tetapi perusahaan melakukan efisiensi,..." Kedelapan adalah perusahaan pailit.

Pasal 165 menyebutkan, "Pengusaha dapat melakukan pemutusan hubungan kerja terhadap pekerja/buruh karena perusahaan pailit,.."

Kesembilan adalah Anda memasuki usia pensiun.

Pasal 167 ayat 1 menyebutkan, "Pengusaha dapat melakukan pemutusan hubungan kerja terhadap pekerja/buruh karena memasuki usia pensiun..." Ini merupakan alasan PHK yang normal.

Kesepuluh adalah Anda mangkir selama lima (5) hari berturut-turut.

Pasal 168, ayat 1 menyebutkan, "Pekerja/buruh yang mangkir selama 5 (lima) hari kerja atau lebih berturut-turut tanpa keterangan secara ter tulis yang dilengkapi dengan bukti yang sah dan telah dipanggil oleh pengusaha 2 (dua) kali secara patut dan tertulis dapat diputus hubungan kerjanya karena dikualifikasikan mengundurkan diri."

Perlu dicatat bahwa keterangan tertulis dengan bukti yang sah harus diserahkan paling lambat pada hari pertama pekerja/buruh masuk bekerja.( http://www.putra-putriindonesia.com/alasan-phk.html) 


\subsubsection{Penyebab dan Alasan Karyawan Berhenti Bekerja}

Gaji yang besar, bos yang baik dan lingkungan kerja yang nyaman tidak menjamin seorang karyawan akan terus bekerja di suatu perusahaan. Bisa saja mereka mengundurkan diri atau resign dari kantor mereka dengan beberapa pertimbangan pribadi yang sifatnya sangat penting dan harus dilakukan. Apa saja alasan yang diberikan karyawan saat mereka memutuskan untuk berhenti bekerja?

Di bawah ini adalah beberapa diantaranya menurut pendapat (http://www.teruskan.com/24704/7-

penyebab-dan-alasan-karyawanberhenti-bekerja.html), yakni:

\section{Gaji yang Terlalu Kecil}

Bagi karyawan yang belum berkeluarga, mungkin gaji UMR DKI Jakarta sebesar Rp. 2.200.000 cukup untuk menanggung biaya hidup selama sebulan bahkan sisanya bisa untuk ditabung.

Tetapi bagi karyawan yang sudah memiliki keluarga dan memiliki anak bahkan mungkin memiliki tanggungan cicilan, mereka membutuhkan income yang lebih tinggi seiring tingginya beban pengeluaran mereka. Masalah gaji adalah masalah sensitif yang merupakan alasan paling besar bagi seseorang untuk berhenti bekerja.

2. Mendapat Tawaran Kerja yang Lebih Baik

Pasti semua orang akan pindah ke perusahaan lain yang menawarkan banyak kelebihan dibanding perusahaan tempatnya bekerja. Hal tersebut sangatlah manusiawi karena pada dasarnya manusia adalah makhluk yang tidak pernah puas.

Namun demikian, ada kemungkinan seseorang bertahan dalam suatu posisi di perusahaan dan menolak tawaran kerja di tempat lain karena: loyalitasnya yang tinggi, sudah merasa nyaman dan terdapat peluang untuk menaiki jenjang karir yang lebih tinggi.
3. Lingkungan dan Suasana Kerja yang Tidak Nyaman

Ketidaknyamanan adalah salah satu faktor yang menjadi pemicu seseorang memutuskan untuk berhenti bekerja. Misalnya saja terjadi konflik antara dua orang karyawan, tekanan persaingan yang terlalu tinggi atau bahkan adanya intimidasi pada karyawan baru.

Seringkali masalah gaji yang kecil tidak begitu bermasalah seandainya lingkungan kerja mereka memberikan rasa nyaman. Bagaimanapun manusia adalah makhluk sosial yang ingin penghargaan dan tidak bisa hidup sendiri.

4. Atasan yang Tidak Disukai

Masalah ini yang kerap kali melatarbelakangi seorang karyawan yang berhenti bekerja. Umumnya mereka merasa mendapat perlakukan yang tidak menyenangkan dari atasan mereka seperti dimarahi, diteriaki bahkan dimaki.

Mereka merasa tidak dihargai dan akhirnya memutuskan untuk resign karena merasa tidak cocok dengan atasan mereka.

5. Lokasi Kerja yang Terlalu Jauh Keluarga Anda tetap ingin tinggal di pinggir kota sementara letak kantor tempat Anda bekerja jaraknya harus ditempuh dengan 2 jam perjalanan. Seringkali Anda merasa sangat keletihan dan waktu Anda begitu banyak Anda habiskan di jalan.

Faktor lokasi kerja yang terlalu jauh memang bisa diatasi dengan pindah rumah tetapi tidak semua karyawan melakukan hal tersebut dan lebih memilih resign kemudian mencari pekerjaan lain yang lebih dekat lokasinya.

6. Kondisi Fisik yang Tidak Memungkinkan

Masalah kesehatan juga dapat membuat seseorang berhenti bekerja. Misalnya saja seorang karyawan yang mengalami kecelakaan dan akhirnya 
mengalami kelumpuhan akhirnya harus resign dari pekerjaannya.

Contoh lain adalah seorang karyawan yang mengalami sakit kanker yang mengharuskannya istirahat total sehingga harus berhenti bekerja.

7. Berhenti Bekerja Demi Keluarga

Bagi para wanita yang hendak berhenti bekerja, alasan keluarga adalah salah satu yang paling banyak diutarakan. Misalnya saja karena ingin mengurus anak, permintaan dari suami, ikut pindah rumah karena dinas suami dan lain sebagainya.

\subsection{Proses Pemberhentian}

Pemberhentian karyawan hendaknya berdasarkan peraturan dan perundang-undangan yang ada agar tidak menimbulkan masalah, dan dilakukan dengan cara sebaik-baiknya, sebagaimana pada saat mereka diterima sebagai karyawan. Dengan demikian, hubungan antara perusahaan dan mantan karyawan tetap terjalin dengan baik. Akan tetapi pada kenyataanya sering terjadi pemberhentian dengan pemecatan, karena konflik yang tidak dapat diatasi lagi, yang seharusnya pemecatan karyawan harus berdasar kepada peraturan dan perundangundangan. Karena setiap karyawan mendapat perlindungan hukum sesuai dengan statusnya.

Menurut Hasibuan (2013;214) proses pemecatan harus menurut prosedur sebagai berikut:

1. Musyawarah karyawan dengan pimpinan perusahaan

2. Musyawarah pimpinan serikat buruh dengan pimpinan perusahaan

3. Musyawarah pimpinan serikat buruh, pimpinan perusahaan, dan P4D

4. Musyawarah pimpinan serikat buruh, pimpinan perusahaan, dan P4P

5. Pemutusan

berdasarkan

Keputusan Pengadilan Negeri

Prosedur ini tidak perlu dilakukan semuanya, jika pada tahap tertentu telah dapat diselesaikan dengan baik. Tetapi jika tidak terselesaikan, penyelesaiannya hanya dengan keputusan pengadilan negeri.

\subsection{Pengaruh Pemberhentian Karyawan Terhadap Perusahaan}

Dengan adanya pemberhentian karyawan tentu berpengaruh sekali terhadap perusahaan terutama masalah dana. Karena pemberhentian karyawan memerlukan dana yang cukup besar diantaranya untuk membayar pensiun atau pesangon karyawan dan untuk membayar tunjangan-tunjangan lainnya. Begitu juga pada saat penarikan kembali karyawan, perusahaan pun mengeluarkan dan yang cukup besar untuk pembayaran kompensasi dan pengembangan karyawan.

Dengan adanya pemberhentian karyawan tersebut tentu sangat berpengaruh sekali terhadap karyawan itu sendiri. Dengan diberhentikan dari pekerjaannya maka berarti karyawan tersebut tidak dapat lagi memenuhi kebutuhan secara maksimal untuk karyawan dan keluarganya. Atas dasar tersebut, maka manajer sumber daya manusia harus sudah dapat memperhitungkan beberapa jumlah uang yang seharusnya diterima oleh karyawan yang behenti, agar karyawan tersebut dapat memenuhi kebutuhannya sampai pada tingkat dianggap cukup.

\subsection{Konsekuensi Pemberhentian}

Menurut Hasibuan (2013;210) konsekuensi-konsekuensi

pemberhentian berdasarkan keinginan perusahaan adalah sebagai berikut :

1. Karyawan dengan status masa percobaan diberhentikan tanpa memberi uang pesangon.

2. Karyawan dengan status kontrak diberhentikan tanpa memberi uang pesangon.

3. Karyawan dengan status tetap, jika diberhentikan harus diberi uang pesangon yang besarnya:

1) Masa kerja sampai satu tahun $=1$ bulan upah bruto 
2) Masa kerja 1 sampai 2 tahun $=2$ bulan upah bruto

3) Masa kerja 2 sampai 3 tahun $=3$ bulan upah bruto

4) Masa kerja 3 tahun dan seterusnya = 4 bulan upah bruto.

Sedangkan besarnya uang jasa sebagai berikut:

1) Masa kerja 5 s.d 10 tahun $=1$ bulan upah bruto.

2) Masa kerja 10 s.d 15 tahun $=2$ bulan upah bruto

3) Masa kerja 15 s.d 20 tahun $=3$ bulan upah bruto

4) Masa kerja 20 s.d 25 tahun $=4$ bulan upah bruto

5) Masa kerja 25 tahun keatas $=5$ bulan upah bruto.

\subsection{Perlindungan Bagi Tenaga}

Kerja Dan $\begin{aligned} & \text { Mencegah } \\ & \text { Perjadinya } \\ & \text { Hubungan Kerja }\end{aligned}$
Mengenai hal ini ditegaskan
dalam pasal 85 Undang-Undang Nomor 25 Tahun 1997 yang berbunyi:

"Pengusaha, pekerja, dan atau serikat pekerja harus melakukan upaya untuk menghindari terjadinya pemutusan hubungan kerja". Menurut

Sedarmayanti (2007;314) Untuk mencegah pemutusan hubungan kerja besar-besaran, perusahaan harus mengambil langkahlangkah :

1. Memperbaiki tingkat kompensasi sehingga lebih memadai.

2. Menciptakan lingkungan kerja yang lebih baik dan menyenangkan.

3. Meninjau kembali pola penempatan karyawan sehingga mendekati bakat dan kemampuan mereka.

4. Menyempurnakan sistem dan prosedur yang berlaku dalam perusahaan supaya lebih efektif dan tidak merugikan para karyawan.

5. Meningkatkan penyediaan fasilitas kerja dan kesejahteraan karyawan.

6. Memperketat pelaksanaan seleksi sehingga karyawan yang masuk betul yang terbaik dan sehat.

\subsection{Semangat Kerja}

semangat kerja merupakan sikap individu atau kelompok terhadap lingkungan kerja mereka dan terhadap kesediaan bekerja sama dengan orang lain secara menyeluruh sesuai kemampuan yang terbaik demi kepentingan organisasi atau perusahaan.

\subsection{Indikator Semangat kerja}

Menurut Dressler $(2001 ; 167)$

dalam semangat kerja dapat diukur melalui presensi pegawai di tempat kerja, tanggung jawabnya terhadap pekerjaan, disiplin kerja, kerja sama dengan pimpinan atau teman sejawat dalam organisasi serta tingkat produktivitas kerja. Untuk memahami unsur-unsur semangat kerja berikut diuraikan penjelasan masing-masing unsur sebagai berikut :

(http://tugasakhiramik.blogspot.co.id/201 3/03/pengertian-semangat-kerja.html)

1. Presensi, merupakan kehadiran pegawai yang berkenaan dengan tugas dan kewajibannya. Pada umumnya instansi / lembaga selalu mengharapkan pegawainya untuk datang dan pulang tepat waktu, sehingga pekerjaan tidak tertunda. Ketidakhadiran seorang pegawai akan berpengaruh terhadap produktivitas kerja, sehingga instansi/lembaga tidak bisa mancapai tujuan secara optimal. Presensi atau kehadiran karyawan dapat diukur melalui : a. Kehadiran pegawai di tempat kerja
b. Ketepatan datang/pulang kerja.

c. Kehadiran pegawai apabila mendapat undangan untuk mengikuti kegiatan atau acara dalam instansi.

2. Disiplin Kerja, merupakan ketaatan seseorang terhadap suatu peraturan yang berlaku dalam organisasi yang menggabungkan diri dalam organisasi itu atas dasar adanya kesadaram dan keinsafan, bukan karena adanya paksaan.

Tingkat kedisiplinan kerja pegawai dapat diukur melalui : 
a. Kepatuhan pegawai terhadap peraturan dan tata tertib di instansi.

b. Kepatuhan pegawai terhadap intruksi yang datang dari atasan.

c. Bekerja sesuai dengan prosedur yang telah ditetapkan.

d. Memakai pakaian seragam sesuai dengan ketentuan yang berlaku.

e. Menggunakan dan memelihara peralatan.

3. Kerjasama, Kerjasama merupakan tindakan konkret seseorang dengan orang lain. Kerjasama juga diartikan sebagai suatu sikap dari individu maupun kelompok terhadap kesukarelaannya untuk bekerja sama agar dapat mencurahkan kemampuannya secara menyeluruh. Keberhasilan atau kegagalan suatu organisasi tergantung pada orang-orang yang terlibat di dalamnya. Untuk itu penting adanya kerjasama yang baik diantara semua pihak dalam organisasi, baik dengan atasan, teman sejawat, maupun bawahan.

Untuk mengukur tingkat kerjasama digunakan kriteria sebagai berikut:

a. Kesadaran pegawai untuk bekerjasama dengan atasan, teman sejawat, maupun bawahannya.

b. Adanya kemauan untuk membantu teman yang mengalami kesulitan dalam melaksanakan pekerjaan.

c. Adanya kemauan untuk memberi dan menerima kritik serta saran dari orang lain.

d. Bagaimana tindakan seseorang apabila mengalami kesulitan dalam melaksanakan pekerjaannya.

4. Tanggung jawab, Tanggung jawab merupakan keharusan pada seseorang yang melaksanakan kegiatan selayaknya apa yang telah diwajibkan kepadanya. Tanggung jawab juga merupakan kewajiban seseorang untuk melaksanakan segala sesuatu yang telah diwajibkan kepadanya, dan jika terjadi kesalahan yang disebabkan karena kelalaiannya, maka seseorang dapat dituntut atau dipersoalkan.

Tingkat tanggung jawab seseorang dapat melalui:

a. Dapat dituntut atau dipersoalkan.

Kesanggupan dalam melaksanakan perintah dan kesanggupan dalam bekerja.

b. Kemampuan menyelesaikan tugas dengan tepat dan benar.

c. Melaksanakan tugas atau perintah yang diberikan dengan sebaikbaiknya.

d. Mempunyai kesadaran bahwa pekerjaan yang diberikan bukan hanya untuk kepentingan instansi, tetapi juga untuk kepentingan dirinya sendiri.

5. Produktivitas Kerja, Produktivitas adalah rasio antara produksi yang dapat dihasilkan dengan keseluruhan biaya yang telah dikeluarkan untuk keperluan produk itu. Produktivitas juga diartikan sebagai efisiensi modal dan waktu yang digunakan untuk menghasilkan barang dan jasa.

Tingkat produktivitas kerja pegawai dapat diukur melalui :
a. Ketepatan penggunaan waktu.
b. Out put / hasil yang dicapai.

\subsection{Pentingnya Semangat Kerja}

Dengan adanya semangat kerja tersebut, maka pekerjaan akan menjadi lebih cepat diselesaikan, kerusakan akan 
dapat dikurangi, absensi akan dapat diperkecil, kemungkinan perpindahan karyawan dapat diperkecil seminimal mungkin, dan sebagainya. Hal ini semua berarti diharapkan bukan saja produktivitas kerja dapat ditingkatkan, tetapi juga ongkos perunit akan diperkecil.

\subsection{Hipotesis}

Didasarkan pada rumusan masalah, maka dapat diambil hipotesis penelitian ini adalah sebagai berikut :

1. Ada pengaruh secara bersama-sama alasan pemberhentian $(X)$ yang terdiri dari keinginan perusahaan $\left(X_{1}\right)$ dan keinginan karyawan $\left(X_{2}\right)$ terhadap semangat kerja karyawan (Y) PT. Jakarta Ponsel XXI Pamekasan.

2. Keinginan perusahaan $\left(X_{1}\right)$ adalah variabel yang paling dominan mempengaruhi semangat kerja karyawan PT. Jakarta Ponsel XXI Pamekasan.

\section{METODOLOGI PENELITIAN}

\subsection{Lokasi Penelitian}

Lokasi dari penelitian ini yakni pada PT. Jakarta Ponsel XXI yang berlokasi di JI. Trunojoyo No.837 Pamekasan yang terletak dipinggir jalan depan pom bensin.

\subsection{Jenis Penelitian} kuantitatif.

Penelitian ini termasuk penelitian

Sehingga berdasarkan tujuan penelitian yang telah ditetapkan, maka jenis penelitian ini adalah penelitian kuantitatif eksplanatif atau penelitian eksplanatori.

\subsection{Populasi dan Sampel \\ 3.3.1 Populasi}

Yang menjadi populasi dalam penelitian ini adalah karyawan PT. Jakarta Ponsel XXI sebanyak 27 Orang.

\subsubsection{Sampel}

sampel dari penelitian ini adalah karyawan yang ada pada PT. Jakarta Ponsel XXI Pamekasan berdasarkan populasi sebanyak 27 orang.

\subsection{Jenis dan Sumber Data \\ 3.4.1 Jenis Data}

Dalam penelitian ini, jenis data yang digunakan adalah data kualitatif dan data kuantitatif. Jenis data kualitatif yang digunakan adalah jenis data kualitatif berskala ordinal.

\subsubsection{Sumber Data}

1. Data Primer

2. Data sekunder

\subsection{Teknik Pengumpulan Data}

Adapun teknik pengumpulan data yang dilakukan adalah sebagai berikut :

1. Survei pendahuluan, berupa penelitian secara umum terhadap karyawan PT. Jakarta Ponsel XXI Pamekasan untuk mengetahui permasalahan yang dihadapi.

2. Penelitian lapangan, sebagai upaya dengan melakukan survei terhadap obyek yang akan diteliti, untuk memperoleh data primer secara langsung melalui :

a. Wawancara

b. Angket

Adapun skala penilaiannya sebagai berikut :
a. Pilihan A dengan nilai skor 5 .
b. Pilihan B dengan nilai skor 4 .
c. Pilihan $\mathrm{C}$ dengan nilai skor 3 .
d. Pilihan D dengan nilai skor 2 .
e. Pilihan E dengan nilai skor 1 .

c. Study kepustakaan

\subsection{Pengujian}

Instrumen

\section{Pengumpulan Data}

\subsubsection{Uji Validitas}

Bertujuan untuk mengetahui sejauh mana validitas data yang diperoleh dari penyebaran angket.

Uji validasi dalam penelitian ini digunakan analisis item yaitu mengkorelasikan skor tiap butir dengan skor total yang merupakan jumlah dari setiap skor butir. Jika ada item yang tidak memenuhi syarat, maka item tersebut tidak akan diteliti lebih lanjut. Sedangkan untuk mengukur validitasnya Singgih, (2000:277) dasar pengambilan keputusan:

a. Jika $r$ hasil positif dan $r$ hasil $>r$ tabel , maka butir atau variabel tersebut valid.

b. Jika $r$ hasil tidak positif dan $r$ hasil $<r$ tabel, maka butir atau variabel tersebut tidak valid. 
Uji validitas penelitian ini dengan menggunakan metode korelasi product moment.

\subsubsection{Uji Reliabilitas}

Menurut Sugiyono (2011;130) "pengujian reliabilitas dapat dilakukan secara eksternal maupun internal. Secara internal reliabilitas instrumen dapat diuji dengan menganalisa konsistensi butir-butir yang ada pada instrumen dengan teknik tertentu ".

Sedangkan untuk mengukur reliabelnya, Singgih (2000:280) dasar pengambilan keputusan :

a. Jika $r$ alpha positif dan $r$ alpha $>r$ tabel , maka butir atau variabel tersebut reliabel.

b. Jika $r$ alpha tidak positif dan $r$ alpha < r tabel , maka butir atau variabel tersebut tidak reliabel.

"Instrument yang dapat dipercaya atau reliabel akan menghasilkan data yang dapat dipercaya. Suatu Instrumen dikatakan reliabel bila memiliki koefisien alpha $>0,5$ atau lebih". Sesuai dengan rambu koefisien dari prihanto (2010:97). (http://davinplus.blogspot.co.id/2012/07/c ara-uji-reliabilitas-instrumen-angket.html)

\subsection{Definisi Operasional}

Definisi operasional variabel dalam penelitian ini adalah :

1. Variabel bebas dengan simbol (X) adalah alasan Pemberhentian, yang terdiri dari :

a. Keinginan Perusahaan $\left(\mathrm{X}_{1}\right)$ artinya karyawan itu menurut perusahaan tidak akan memberikan keuntungan lagi. Keinginan perusahaan dapat diukur dengan indikator:

1). Karyawan kurang cakap

2). Tidak mencapai target

3). Melakukan tindakan yang merugikan

b. Keinginan Karyawan $\left(X_{2}\right)$ terjadi karena berbagai hal sehingga karyawan tersebut kurang mendapatkan kepuasan kerja diperusahaan bersangkutan. Keinginan karyawan dapat diukur dengan indikator :

1). Balas jasanya rendah
2). Mendapatkan pekerjaan yang lebih baik

3). Melanjutkan pendidikan

2. Variabel terikat dengan simbol $(Y)$ adalah Semangat Kerja Karyawan yaitu kondisi seseorang yang menunjang dirinya untuk melakukan pekerjaan lebih cepat dan lebih baik di dalam sebuah perusahaan. Semangat kerja Karyawan yang diukur dengan indikator sebagai berikut :

1). Presensi.

2). Disiplin kerja.

3.) Kerja sama.

4). Tanggung jawab.

5). Produktivitas kerja.

\subsection{Teknik Analisis Data dan Uji Hipotesis}

3.8.1 Teknik Analisis Data

a. Analisis kualitatif adalah suatu analisa dengan menggunakan interprestasi dan pengembangan pemikiran dengan tujuan untuk memberikan gambaran tentang obyek yang akan diteliti.

b. Analisis kuantitatif.

Adapun teknik ini dengan menggunakan persamaan regresi linier Berganda menurut pendapat Sugiyono (2011;192). Sedangkan untuk memberikan pedoman dan koefisien korelasi ini, maka penulis mengambil pendapat Sugiyono (2009:214)

\subsubsection{Uji Hipotesis}

a. Uji F

Uji $F$ digunakan untuk membuktikan hipotesis pertama yang merupakan pengujian secara simultan.

Dengan demikian $F$ hitung dengan $F$ tabel pada $\alpha \quad 0,05$ dengan hasil perhitungan :

1. Apabila $F$ hitung $>F$ tabel maka $\mathrm{Hi}$ diterima dan $\mathrm{Ho}$ ditolak.

2. Apabila $\mathrm{F}$ hitung $<\mathrm{F}$ tabel maka $\mathrm{Ho}$ diterima dan $\mathrm{Hi}$ ditolak.

b. Uji t

Uji $t$ digunakan untuk membuktikan hipotesis yang merupakan pengujian secara parsial dari masingmasing variabel bebas terhadap variabel 
terikat dan untuk mencari nilai $\mathrm{t}$ yang paling tinggi atau dominan.

Dengan membandingkan $\mathrm{t}$ hitung dan $\mathrm{t}$ tabel a 0,05 maka :

1. $\mathrm{t}$ hitung $<\mathrm{t}$ tabel maka $\mathrm{H}_{0}$ diterima dan $\mathrm{H}_{\mathrm{I}}$ ditolak, artinya variabel bebas kurang menjelaskan variabel terikatnya.

2. $\mathrm{t}$ hitung $>\mathrm{t}$ tabel $\mathrm{H}_{\mathrm{O}}$ ditolak dan $\mathrm{H}_{\mathrm{I}}$ diterima, artinya variabel bebasnya dapat menjelaskan variabel terikatnya.

\section{HASIL PENELITIAN DAN}

\section{PEMBAHASAN}

4.1 HASIL PENELITIAN

4.1.1 Gambaran Umum PT. Jakarta Ponsel XXI Pamekasan

PT. Jakarta Ponsel XXI

Pamekasan yang berada di Jl. Trunojoyo No.837 depan pom bensin pamekasan berdiri sejak tanggal 31 mei 2015, yang merupakan pusat penjualan berbagai jenis HP, Smartphone, Tablet, kartu perdana dan Aksesoris yang lengkap, murah, terpercaya serta TERMURAH SE-INDONESIA. Perusahaan ini merupakan anak cabang dari PT. Ponsel XXI yang berpusat di kota Surabaya.

PT. Jakarta Ponsel XXI Pamekasan letaknya sangat strategis, mudah dijangkau dan dekat dengan keramaian, selain harga yang murah perusahaan ini memiliki berbagai macam bonus untuk menarik minat konsumen untuk membeli produk di perusahaan ini sebagai strategi pemasaran.

\subsubsection{Hasil Data Penelitian}

Berdasarkan penetapan sampel yang ada pada PT. Jakarta Ponsel XXI Pamekasan sebanyak 27 responden dengan 11 item pertanyaan didapatkan hasil data pada lampiran 2. Dan karakteristik karyawan PT. Jakarta Ponsel XXI Pamekasan dapat dilihat dari tabel 4.1 berikut ini

1. Karakteristik responden berdasarkan jenis kelamin

Tabel 4.1

Karakteristik Responden Berdasarkan Jenis Kelamin

\begin{tabular}{|c|c|c|c|}
\hline No & Jenis Kelamin & Jumlah & Persentase \\
\hline 1 & Laki-Laki & 21 & $77,8 \%$ \\
\hline 2 & Perempuan & 6 & $22,2 \%$ \\
\hline \multicolumn{2}{|r|}{ Total } & 27 & $100 \%$ \\
\hline
\end{tabular}

Sumber : data diolah

Berdasarkan tabel 4.1 diatas, dapat diketahui jumlah responden berdasarkan jenis kelaminnya yaitu 21 orang berjenis kelamin laki-laki dengan persentase $77,8 \%$ dan 6 orang berjenis kelamin perempuan dengan persentase

\section{Karakteristik responden berdasarkan pendidikan terakhir}

Tabel 4.2

Karakteristik Responden Berdasarkan Pendidikan Terakhir

\begin{tabular}{|c|c|c|}
\hline Pendidikan & Jumlah & Persentase \\
\hline SMA & 27 & $100 \%$ \\
\hline
\end{tabular}

Sumber : data diolah

Berdasarkan Tabel 4.2 diatas, dapat diketahui jumlah responden berdasarkan pendidikan terakhirnya yaitu 27 orang berpendidikan terakhir SMA dengan persentase $100 \%$. Hal ini

\subsection{Analisa Data Dan Pembahasan}

\subsubsection{Hasil Uji Validitas}

22,2\%. Hal ini menunjukkan bahwa sebagian besar responden yang terbesar adalah laki-laki, sehingga dapat dikatakan bahwa laki-laki yang lebih dominan dalam menjalankan tugasnya. 
Uji validitas didapatkan dari penyebaran angket pada responden yang akan diuji terlebih dahulu apakah angket tersebut valid atau tidak dari semua variabel bebas yang terdiri dari keinginan perusahaan dan keinginan karyawan serta variabel terikat yaitu semangat kerja karyawan PT. Jakarta Ponsel XXI Pamekasan dengan menggunakan bantuan program Statistical Program for Social and Science (SPSS).

Dari hasil SPSS versi 20, $r$ hasil bisa dilihat pada kolom Corrected ItemTotal Correlation dan kemudian nilai ini dibandingkan nilai $r$ tabel (lihat pada lampiran tabel r), pada tingkat signifikasi
0,05 dengan jumlah responden 27 didapat $r$ tabel sebesar 0,381 .

Dengan derajad kepercayaan sebesar $95 \%$ atau 0,05 variabel dinyatakan valid apabila sesuai dengan dasar ketentuan menurut Singgih (2000:277) memiliki kriteria sebagai berikut :

a. Jika $r$ hasil positif dan $r$ hasil $>r$ tabel , maka butir atau variabel tersebut valid.

b. Jika $r$ hasil tidak positif dan $r$ hasil $<r$ tabel , maka butir atau variabel tersebut tidak valid.

Hasil uji validitas dari masing-masing variabel penelitian sebagai berikut :

\section{Uji Validitas Variabel Keinginan Perusahaan $\left(X_{1}\right)$}

Dengan menggunakan bantuan program Statistical Program Social of Science (SPSS) versi 20 . Hasil perhitungan dari uji validitas variabel keinginan perusahaan $\left(X_{1}\right)$ dapat dilihat pada tabel 4.3 sebagai berikut :

Tabel 4.3

Hasil Uji Validitas Keinginan Perusahaan $\left(\mathrm{X}_{1}\right)$

\begin{tabular}{|c|l|c|c|}
\hline \multirow{2}{*}{ No } & \multicolumn{2}{|c|}{ Hasil uji validitas indikator $\mathbf{X}_{\mathbf{1}}$} & \multirow{2}{*}{ Keterangan } \\
\cline { 2 - 3 } & \multicolumn{1}{|c|}{ Kenginan Perusahan } & Nilai $\mathbf{r}$ hasil & \\
\hline 1 & Karyawan kurang cakap & 0,438 & Valid \\
\hline 2 & Tidak mencapai target & 0,341 & Tidak Valid \\
\hline 3 & Melakukan tindakan yang merugikan & 0,358 & Tidak Valid \\
\hline
\end{tabular}

\section{Sumber : data diolah}

Berdasarkan tabel 4.3 diatas, dapat diuraikan beberapa penjelasan dibawah ini:

1. PT. Jakarta Ponsel XXI Pamekasan akan memberhentikan karyawan jika karyawan kurang cakap dalam bekerja $=0,438>0,381$ (Valid).

2. Jika karyawan tidak mencapai target yang diinginkan PT. Jakarta Ponsel XXI Pamekasan, maka karyawan akan diberhentikan bekerja $=0,341$ $<0,381 \quad$ (Tidak Valid).

3. Karyawan yang melakukan tindakan yang merugikan PT. Jakarta Ponsel XXI Pamekasan akan diberhentikan $=0,358<0,381$ ( Tidak Valid).
Dari hasil uji validitas tersebut dengan 3 indikator dari variabel keinginan perusahaan terdiri dari 1 item Valid dan 2 item tidak valid, maka item yang tidak valid tersebut dikeluarkan atau tidak boleh diikutkan dalam proses selanjutnya sedangkan untuk yang valid dapat diikutkan dalam proses selanjutnya.

2. Uji Validitas Variabel Keinginan Karyawan $\left(\mathbf{X}_{2}\right)$

Dengan menggunakan bantuan program Statistical Program Social of Science (SPSS) versi 20. Hasil perhitungan dari uji validitas variabel keinginan karyawan $\left(X_{2}\right)$ dapat dilihat pada tabel 4.4 sebagai berikut :

Tabel 4.4

Hasil Uji Validitas Keinginan Karyawan $\left(X_{2}\right)$

\begin{tabular}{|c|l|c|c|}
\hline \multirow{2}{*}{ No } & \multicolumn{2}{|c|}{ Hasil uji validitas indikator $\mathbf{X}_{\mathbf{2}}$} & \multirow{2}{*}{ Keterangan } \\
\cline { 2 - 3 } & \multicolumn{1}{|c|}{ Kenginan Karyawan } & Nilai $\mathbf{r}$ Hasil & \\
\hline 1 & Balas jasanya rendah & 0,675 & Valid \\
\hline 2 & Mendapatkan pekerjaan yang lebih baik & 0,666 & Valid \\
\hline 3 & Melanjutkan pendidikan & 0,309 & Tidak valid \\
\hline
\end{tabular}

Sumber : data diolah 
Berdasarkan tabel 4.4 diatas, dapat diuraikan beberapa penjelasan dibawah ini:

1. Karyawan dapat mengajukan untuk berhenti bekerja dari PT. Jakarta Ponsel XXI Pamekasan Jika pemberian gaji atau balas jasanya rendah dan tidak sesuai dengan peraturan pemerintah $=0,675>$ 0,381 ( Valid ).

2. Karyawan dapat mengajukan surat pengunduran berhenti bekerja dari PT. Jakarta Ponsel XXI Pamekasan karena mendapatkan pekerjaan yang lebih baik ditempat lain $=0,666$ $>0,381$ ( Valid).

3. Karyawan juga dapat mengajukan surat pengunduran berhenti bekerja dari PT. Jakarta Ponsel XXI Pamekasan karena untuk melanjutkan pendidikan $=0,309<$ 0,381 ( Tidak Valid).

Dari hasil uji validitas tersebut dengan 3 indikator dari variabel keinginan karyawan terdiri dari 2 item Valid dan 1 item tidak valid, maka item yang tidak valid tersebut dikeluarkan atau tidak boleh diikutkan dalam proses selanjutnya sedangkan untuk yang valid dapat diikutkan dalam proses selanjutnya.

3. Uji Validitas Variabel Semangat Kerja karyawan $(\mathrm{Y})$

Dengan menggunakan bantuan program Statistical Program Social of Science (SPSS) Hasil perhitungan dari uji validitas variabel semangat kerja karyawan $(Y)$ dapat dilihat pada tabel 4.5 sebagai berikut :

Tabel 4.5

Hasil Uji Validitas Semangat Kerja Karyawan (Y)

\begin{tabular}{|c|l|c|c|}
\hline \multirow{2}{*}{ No } & \multicolumn{2}{|c|}{ Hasil uji validitas indikator $\mathbf{~}$} & \multirow{2}{*}{ Keterangan } \\
\cline { 2 - 3 } & Semangat kerja karyawan & Nilai $\mathbf{r}$ hasil & \\
\hline 1 & Presensi & 0,663 & Valid \\
\hline 2 & Disiplin kerja & 0,791 & Valid \\
\hline 3 & Kerja sama & 0,450 & Valid \\
\hline 4 & Tanggung jawab & 0,455 & Valid \\
\hline 5 & Produktivitas kerja & 0,791 & Valid \\
\hline
\end{tabular}

\section{Sumber : data diolah}

Berdasarkan tabel 4.5 diatas, dapat diuraikan beberapa penjelasan dibawah ini:

1. Jika presensi yang karyawan berikan baik dan bagus, maka karyawan akan dipertahankan untuk bekerja di PT. Jakarta Ponsel XXI Pamekasan $=0,663>0,381$ ( Valid).

2. Karyawan harus selalu meningkatkan disiplin kerja demi kemajuan PT. Jakarta Ponsel XXI Pamekasan $=0,791>0,381$ ( Valid ).

3. Kemajuan PT. Jakarta Ponsel XXI Pamekasan ditentukan dari kerja sama antar karyawan lainnya dan dengan manajemen perusahaan $=$ $0,450>0,381$ ( Valid ).
4. Segala kegiatan dan barang-barang yang ada dalam PT. Jakarta Ponsel merupakan tanggung jawab karyawan secara penuh $=0,455>$ 0,381 ( Valid).

5. Karyawan dapat memberikan kritikan atau saran terhadap PT. Jakarta Ponsel XXI Pamekasan guna untuk meningkatkan Produktivitas kerja $=0,791>0,381$ Valid).

Dari hasil uji validitas tersebut dengan 5 indikator dari variabel semangat kerja karyawan semua item valid, maka semua item tersebut dapat diikutkan dalam proses selanjutnya.

\subsubsection{Hasil Uji Reliabilitas}

Tabel 4.6

Hasil Uji Reliabilitas Variabel Bebas Dan Terikat

\begin{tabular}{|c|c|c|c|}
\hline \multirow{2}{*}{ Variabel } & \multicolumn{2}{|c|}{ Hasil Uji Reliabiltas Variabel Bebas dan Terikat } & \multirow{2}{*}{ Keterangan } \\
\cline { 2 - 3 } & Keterangan & r Alpha & \\
\hline$X_{1}$ & Keinginan perusahaan & 0,750 & Handal \\
\hline
\end{tabular}




\begin{tabular}{|c|l|c|c|}
\hline $\mathrm{X}_{2}$ & Keinginan karyawan & 0,776 & Handal \\
\hline $\mathrm{Y}$ & Semangat kerja karyawan & 0,780 & Handal \\
\hline
\end{tabular}

Sumber : data diolah

Uji reliabilitas digunakan untuk mengetahui sejauh mana alat atau instrument data dapat memberikan hasil yang relatif sama meski dilakukan pengukuran kembali pada subyek yang sama, dengan tujuan dari uji reliabilitas adalah untuk mengetahui tingkat reliabilitas dari alat atau instrument data penelitian.

Dengan menggunakan metode Alpha Cronbach dan menggunakan bantuan program Statistical Program Social of Science (SPSS). Hasil perhitungan dari uji reliabilitas dengan SPSS dapat dilihat pada tabel 4.6.

Berdasarkan hasil uji reliabilitas variabel bebas dan terikat pada tabel 4.6 diatas baik variabel bebas yang terdiri dari keinginan perusahaan $\left(X_{1}\right.$ dengan $r$ Alpha $=0,750>$ koefisien Alpha 0,5) dan keinginan karyawan $\left(X_{2}\right.$ dengan $r$ Alpha $=0,776>$ koefisien Alpha 0,5 ) serta variabel terikat yakni semangat kerja karyawan $(Y$ dengan $r$ Alpha $=0,780>$ koefisien Alpha 0,5) memiliki tingkat kehandalan yang dapat digunakan dalam penelitian atau hasil dari pengujian tersebut sudah bisa dikatakan reliabel atau handal, karena ketiga variabel mempunyai koefisien $>0,5$.

\subsubsection{Analisa Kualitatif}

Untuk memberikan gambaran tentang obyek yang diteliti berdasarkan hasil dari jawaban responden, maka dapat disusun suatu distribusi jawaban responden dari setiap variabel dengan menggunakan bantuan program Statistical Program of Social and Science (SPSS) dengan menggunakan teknik skala likert sebagi berikut :

\section{Distribusi Frekuensi Jawaban Responden Untuk Variabel Keinginan Perusahaan $\left(\mathrm{X}_{1}\right)$.}

Tabel 4.7

Distribusi Jawaban Responden Variabel Keinginan Perusahaan $\left(\mathrm{X}_{1}\right)$

\begin{tabular}{|c|c|c|c|c|c|c|c|c|c|c|c|}
\hline \multirow{3}{*}{$\begin{array}{l}\mathbf{I} \\
\mathbf{N} \\
\mathbf{D} \\
\mathbf{I} \\
\mathrm{K} \\
\mathbf{A} \\
\mathbf{T} \\
\mathbf{O} \\
\mathbf{R}\end{array}$} & \multicolumn{10}{|c|}{$\begin{array}{l}\text { Distribusi jawaban responden variabel keinginan perusahaan } \\
\qquad\left(X_{1}\right)\end{array}$} & \multirow{3}{*}{$\begin{array}{l}\text { Rata- } \\
\text { rata }\end{array}$} \\
\hline & \multicolumn{2}{|c|}{$\begin{array}{c}\text { Sangat } \\
\text { Tidak } \\
\text { Setuju } \\
\text { (1) }\end{array}$} & \multicolumn{2}{|c|}{$\begin{array}{c}\text { Tidak } \\
\text { Setuju } \\
(2) \\
\end{array}$} & \multicolumn{2}{|c|}{$\begin{array}{c}\text { Cukup } \\
\text { Setuju } \\
(3) \\
\end{array}$} & \multicolumn{2}{|c|}{$\begin{array}{c}\text { Setuju } \\
\text { (4) }\end{array}$} & \multicolumn{2}{|c|}{$\begin{array}{c}\text { Sangat } \\
\text { Setuju } \\
\\
(5) \\
\end{array}$} & \\
\hline & $F$ & $\%$ & $\mathbf{F}$ & $\%$ & $F$ & $\%$ & $\mathbf{F}$ & $\%$ & $F$ & $\%$ & \\
\hline $\mathrm{X} 1.1$ & 0 & & 1 & 3 & & 25 & 1 & & & 22,2 & 3,89 \\
\hline$X 1.2$ & 0 & & & 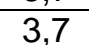 & & 29 & 1 & 48 & & 18,5 & 3,81 \\
\hline X1.3 & 0 & 0,0 & 3 & 11,1 & 6 & 22,2 & 9 & 33,3 & $y$ & 33,3 & 3,89 \\
\hline
\end{tabular}

Sumber : data diolah

Dari hasil jawaban responden untuk variabel keinginan perusahaan $\left(\mathrm{X}_{1}\right)$ yang terdiri dari indikator karyawan kurang cakap $\left(\mathrm{X}_{1.1}\right)$, tidak mencapai target $\left(X_{1.2}\right)$ dan melakukan tindakan yang merugikan $\left(X_{1.3}\right)$ dapat dilihat pada tabel 4.7.

Berdasarkan tabel 4.7 Diatas, maka dapat diuraikan beberapa keterangan distribusi frekuensi jawaban responden dari variabel keinginan perusahaan dengan beberapa indikator sebagai berikut :
1. Indikator karyawan kurang cakap $\left(X_{1.1}\right)$ dari 27 orang sebanyak 1 orang atau 3,7 \% menjawab tidak setuju (2), 7 orang atau 25,9\% menjawab cukup setuju (3), 13 orang atau $48,1 \%$ menjawab setuju (4) dan 6 orang atau 22,2 \% menjawab sangat setuju (5) dengan rata-ratanya sebesar 3,89 (baik).

2. Indikator tidak mencapai target $\left(X_{1.2}\right)$ dari 27 orang sebanyak 1 orang atau $3,7 \%$ menjawab tidak setuju (2), 8 orang atau 29,6 \% menjawab cukup 
setuju (3), 13 orang atau $48,1 \%$ menjawab setuju (4) dan 5 orang atau $18,5 \%$ menjawab sangat setuju (5) dengan rata-ratanya sebesar 3,81 (baik).

3. Indikator melakukan tindakan yang merugikan $\left(\mathrm{X}_{1.3}\right)$ dari 27 orang

4.

2. Distribusi Frekuensi Jawaban Responden Untuk Variabel Keinginan Karyawan $\left(\mathrm{X}_{2}\right)$

Tabel 4.8

Distribusi Jawaban Responden Variabel Keinginan Karyawan $\left(\mathrm{X}_{2}\right)$

\begin{tabular}{|c|c|c|c|c|c|c|c|c|c|c|c|}
\hline \multirow{3}{*}{$\begin{array}{l}\mathbf{I} \\
\mathbf{N} \\
\mathbf{D} \\
\mathbf{I} \\
\mathbf{K} \\
\mathbf{A} \\
\mathbf{T} \\
\mathbf{O} \\
\mathbf{R}\end{array}$} & \multicolumn{10}{|c|}{ Distribusi jawaban responden variabel keinginan karyawan $\left(\mathrm{X}_{2}\right)$} & \multirow{3}{*}{$\begin{array}{l}\text { Rata- } \\
\text { rata }\end{array}$} \\
\hline & \multicolumn{2}{|c|}{$\begin{array}{c}\text { Sangat } \\
\text { Tidak } \\
\text { Setuju } \\
\text { (1) }\end{array}$} & \multicolumn{2}{|c|}{$\begin{array}{c}\text { Tidak } \\
\text { Setuju } \\
(2)\end{array}$} & \multicolumn{2}{|c|}{$\begin{array}{c}\text { Cukup } \\
\text { Setuju } \\
(3)\end{array}$} & \multicolumn{2}{|c|}{$\begin{array}{l}\text { Setuju } \\
\text { (4) }\end{array}$} & \multicolumn{2}{|c|}{$\begin{array}{c}\text { Sangat } \\
\text { Setuju } \\
\text { (5) }\end{array}$} & \\
\hline & $\mathbf{F}$ & $\%$ & $\mathbf{F}$ & $\%$ & $\mathbf{F}$ & $\%$ & $\mathbf{F}$ & $\%$ & $F$ & $\%$ & \\
\hline $\mathrm{X} 2.1$ & 0 & 0,0 & 2 & 7,4 & 13 & 48,1 & 6 & 22,2 & 6 & 22,2 & 3,59 \\
\hline $\mathrm{X} 2.2$ & 0 & 0,0 & 0 & 0 , & 7 & 25,9 & 9 & 3 & 11 & 40,7 & 4,15 \\
\hline $\mathrm{X} 2.3$ & 0 & 0,0 & 0 & 0,0 & 4 & 14,8 & 16 & 59,3 & 7 & 25,9 & 4,11 \\
\hline
\end{tabular}

Sumber : data diolah

Dari hasil jawaban responden untuk variabel keinginan karyawan $\left(\mathrm{X}_{2}\right)$ yang terdiri dari indikator balas jasanya rendah $\left(X_{2.1}\right)$, mendapatkan pekerjaan yang lebih baik $\left(X_{2.2}\right)$ dan melanjutkan pendidikan $\left(\mathrm{X}_{2.3}\right)$ dapat dilihat pada tabel 4.8 .

Berdasarkan tabel 4.8 Diatas, maka dapat diuraikan beberapa keterangan distribusi frekuensi jawaban responden dari variabel keinginan karyawan dengan beberapa indikator sebagai berikut :

1. Indikator balas jasanya rendah $\left(\mathrm{X}_{2.1}\right)$ dari 27 orang sebanyak 2 orang atau $7,4 \%$ menjawab tidak setuju (2), 13 orang atau $48,1 \%$ menjawab cukup setuju (3), 6 orang atau $22,2 \%$ 4. menjawab setuju (4) dan 6 orang

3. Distribusi Frekuensi Jawaban Responden Untuk Variabel Semangat Kerja Karyawan (Y).

Tabel 4.9

Distribusi Jawaban Responden Variabel Semangat Kerja Karyawan $(Y)$

\begin{tabular}{|c|c|c|c|c|c|c|}
\hline I & \multicolumn{3}{|c|}{ Distribusi jawaban responden variabel semangat kerja karyawan } & $\begin{array}{c}\text { Rata- } \\
\text { N }\end{array}$ \\
rata \\
D & Sangat & Tidak & Cukup & & Sangat & \\
I & Tidak & Setuju & Setuju & Setuju & Setuju & \\
K & Setuju & & & & \\
A & $(1)$ & $(2)$ & $(3)$ & $(4)$ & $(5)$ & \\
\hline
\end{tabular}

sebanyak 3 orang atau $11,1 \%$ setuju (4) dan 9 orang atau 33,3\% menjawab sangat setuju (5) dengan rata-ratanya sebesar 3,89 (baik). (3), 9 orang atau $33,3 \%$ menjawab

atau $22,2 \%$ menjawab sangat setuju (5) dengan rata-ratanya sebesar 3,59 (baik).

2. Indikator mendapatkan pekerjaan yang lebih baik $\left(X_{2.2}\right)$ dari 27 orang sebanyak 7 orang atau $25,9 \%$ menjawab cukup setuju (3), 9 orang atau $33,3 \%$ menjawab setuju (4) dan 11 orang atau $40,7 \%$ menjawab sangat setuju (5) dengan rataratanya sebesar 4,15 (baik).

3. Indikator melanjutkan pendidikan $\left(X_{2.3}\right)$ dari 27 orang sebanyak 4 orang atau $14,8 \%$ menjawab cukup setuju (3), 16 orang atau 59,3\% menjawab setuju (4) dan 7 orang atau $25,9 \%$ menjawab sangat setuju (5) dengan rata-ratanya sebesar 4,11 (baik). 


\begin{tabular}{|c|c|c|c|c|c|c|c|c|c|c|c|}
\hline $\mathbf{T}$ & & $\%$ & $\mathbf{F}$ & $\%$ & $\mathbf{F}$ & $\%$ & $\mathbf{F}$ & $\%$ & $\mathbf{F}$ & $\%$ & \\
$\mathbf{R}$ & $\mathbf{F}$ & & & & & & & & & & \\
\hline $\mathrm{Y} 1$ & 0 & 0,0 & 0 & 0,0 & 13 & 48,1 & 6 & 22,2 & 8 & 29,6 & 3,81 \\
\hline $\mathrm{Y} 2$ & 0 & 0,0 & 0 & 0,0 & 8 & 29,6 & 12 & 44,4 & 7 & 25,9 & 3,96 \\
\hline $\mathrm{Y} 3$ & 0 & 0,0 & 0 & 0,0 & 3 & 11,1 & 13 & 48,1 & 11 & 40,7 & 4,30 \\
\hline $\mathrm{Y} 4$ & 0 & 0,0 & 0 & 0,0 & 12 & 44,4 & 8 & 29,6 & 7 & 25,9 & 3,81 \\
\hline $\mathrm{Y} 5$ & 0 & 0,0 & 0 & 0,0 & 8 & 29,6 & 12 & 44,4 & 7 & 25,9 & 3,96 \\
\hline
\end{tabular}

Sumber : data diolah

Dari hasil jawaban responden untuk variabel semangat kerja karyawan (Y) yang terdiri dari indikator presensi $\left(Y_{1}\right)$, disiplin kerja $\left(Y_{2}\right)$, kerja sama $\left(Y_{3}\right)$, tanggung jawab $\left(Y_{4}\right)$ dan produktivitas kerja $\left(\mathrm{Y}_{5}\right)$ dapat dilihat pada tabel 4.9.

Berdasarkan tabel 4.9 Diatas, maka dapat diuraikan beberapa keterangan distribusi frekuensi jawaban responden dari variabel semangat kerja karyawan dengan beberapa indikator sebagai berikut :

1. Indikator presensi $\left(Y_{1}\right)$ dari 27 orang sebanyak 13 orang atau 48,1\% menjawab cukup setuju (3), 6 orang atau 22,2 \% menjawab setuju (4) dan 8 orang atau $29,6 \%$ menjawab sangat setuju (5) dengan rataratanya sebesar 3,81 (baik).

2. Indikator disiplin kerja $\left(\mathrm{Y}_{2}\right)$ dari 27 orang sebanyak 8 orang atau 29,6 $\%$ menjawab cukup setuju (3), 12 orang atau $44,4 \%$ menjawab setuju (4) dan 7 orang atau 25,9 \% menjawab sangat setuju (5) dengan rata-ratanya sebesar 3,96 (baik).

3. Indikator kerja sama $\left(\mathrm{Y}_{3}\right)$ dari 27 orang sebanyak 3 orang atau 11,1 $\%$ menjawab cukup setuju (3), 13 orang atau $48,1 \%$ menjawab setuju (4) dan 11 orang atau 40,7\% menjawab sangat setuju (5) dengan rata-ratanya sebesar 4,30 (baik).

4. Indikator tanggung jawab $\left(Y_{4}\right)$ dari 27 orang sebanyak 12 orang atau 44,4 \% menjawab cukup setuju (3), 8 orang atau $29,6 \%$ menjawab setuju (4) dan 7 orang atau $25,9 \%$ menjawab sangat setuju (5) dengan rata-ratanya sebesar 3,81 (baik).

5. Indikator produktivitas kerja $\left(Y_{5}\right)$ dari 27 orang sebanyak 8 orang atau $29,6 \%$ menjawab cukup setuju (3), 12 orang atau $44,4 \%$ menjawab setuju (4) dan 7 orang atau $25,9 \%$ menjawab sangat setuju (5) dengan rata-ratanya sebesar 3,96 (baik).

\subsubsection{Analisa Kuantitatif}

Untuk memberikan gambaran tentang kondisi objek yang akan diteliti berdasarkan perhitungan statistik angkaangka dari data yang didapat dengan teknik regresi linier berganda dan dengan menggunakan bantuan program Statistical Program of Social and Science (SPSS). Dapat dilihat pada tabel 4.10:

Tabel 4.10

Hasil Perhitungan Statistik Dengan Regresi Linier Berganda

\begin{tabular}{|c|l|c|}
\hline \multirow{2}{*}{ No } & \multicolumn{2}{|c|}{ Hasil perhitungan statistik dengan regresi linier berganda } \\
\cline { 2 - 3 } & \multicolumn{1}{|c|}{ Variabel-Variabel Alasan Pemberhentian } & Koefisien regresi \\
\hline 1 & Konstanta & 0,249 \\
\hline 2 & Keinginan perusahaan $\left(\mathrm{X}_{1}\right)$ & 1,033 \\
\hline 3 & Keinginan karyawan $\left(\mathrm{X}_{2}\right)$ & 0,057 \\
\hline
\end{tabular}

Sumber : data diolah

Berdasarkan tabel 4.10 Diatas maka dapat diketahui koefisien-koefisien regresi dan konstanta serta dapat disusun persamaan regresi linier berganda sebagai berikut :

$$
Y=0,249+1,033 X_{1}+0,057 X_{2}+E
$$

Dari persamaan tersebut dapat diuraikan keterangan yaitu :

a. Konstanta $=0,249$

Jika variabel bebas yang terdiri dari keinginan perusahaan dan keinginan karyawan dianggap tetap (konstant) atau $\mathrm{X}$ 
$=0$, maka pengaruh dari variabel bebas terhadap semangat kerja karyawan PT. Jakarta Ponsel XXI Pamekasan memiliki nilai yang positif atau dapat dikatakan bertambah sebesar 0,249 atau sebesar 24,9\%.

b. Keinginan perusahaan $\left(X_{1}\right)=$ 1,033

Jika faktor keinginan perusahaan dapat ditingkatkan sebesar satu-satuan dari faktor keinginan perusahaan maka ada kontribusi positif atau bertambah terhadap semangat kerja karyawan PT. Jakarta Ponsel XXI Pamekasan sebesar 1,033 atau sebesar $10,33 \%$.

c. Keinginan karyawan $\left(X_{2}\right)=0,057$ Jika faktor keinginan karyawan dapat ditingkatkan sebesar satu-satuan dari faktor keinginan karyawan maka ada kontribusi positif atau bertambah terhadap semangat kerja karyawan PT. Jakarta Ponsel XXI Pamekasan sebesar 0,057 atau sebesar 5,7\%.

Sehingga dapat diambil kesimpulan bahwa dengan kedua variabel bebas yang terdiri dari keinginan perusahaan dan keinginan karyawan terhadap semangat kerja karyawan PT. Jakarta Ponsel XXI Pamekasan dapat ditingkatkan sebesar 0,249 atau sebesar $24,9 \%$.

Sedangkan untuk mengetahui hasil koefisien korelasi dan koefisien determinan dapat dilihat pada tabel 4.11 dibawah

Tabel 4.11

Hasil Koefisien Korelasi Dan Koefisien Determinan

\begin{tabular}{|c|l|c|c|}
\hline \multirow{2}{*}{ No } & \multicolumn{3}{|c|}{ Hasil koefisien korelasi dan koefisien determinan } \\
\cline { 2 - 4 } & Koefisien & $\mathbf{R}$ & $\mathbf{R}^{\mathbf{2}}$ (R Square) \\
\hline $\mathbf{1}$ & Nilai Koefisien & 0,947 & 0,896 \\
\hline $\mathbf{2}$ & Tingkat Hubungan & Sangat Kuat & Sangat Kuat \\
\hline
\end{tabular}

Sumber : data diolah

Dengan menggunakan bantuan program

Statistical Program of Social and Science (SPSS) Didapatkan hasil koefisien korelasi dan koefisien determinan pada tabel 4.11.

Dari tabel 4.11 diatas dapat diketahui hasil analisa korelasi memiliki tingkat hubungan yang sama-sama sangat kuat dengan nilai koefisien korelasi $(R)$ sebesar 0,947 dan nilai koefisien determinan ( $R^{2}$ atau $R$ square) sebesar 0,896 artinya hasil koefisien korelasi dan koefisien determinan kontribusi dari faktor alasan pemberhentian keinginan perusahaan dan alasan pemberhentian keinginan karyawan secara bersama-sama terhadap semangat kerja karyawan PT. Jakarta Ponsel XXI Pamekasan ada pada tingkat hubungan yang sangat kuat.
Namun ada faktor lain yang dapat mempengaruhi semangat kerja karyawan PT. Jakarta Ponsel XXI Pamekasan selain dari kedua faktor keinginan perusahaan dan keinginan karyawan yang belum diketahui dan hal ini perlu lebih dikaji lagi oleh pihak pimpinan PT. Jakarta Ponsel XXI Pamekasan yang nilainya dapat diambil dari $100 \%$ - nilai koefisien determinan $\left(R^{2}\right.$ atau $R$ Square) sebesar 0,896 atau $89,6 \%=10,4 \%$.

\subsubsection{Uji Hipotesis}

a. Uji $F$

Dengan menggunakan bantuan program Statistical Program for Social and Science (SPSS) versi 20 didapatkan hasil perhitungan Uji F pada tabel 4.12 dibawah ini : 
Tabel 4.12

Hasil Perhitungan Uji F

\begin{tabular}{|c|c|c|c|}
\hline \multicolumn{4}{|c|}{ Hasil Perhitungan Uji F } \\
\hline Koefisien Regresi & F hitung & F tabel & Keterangan \\
\hline$X$ & 103,908 & 3,40 & Diterima \\
\hline
\end{tabular}

Sumber : data diolah dari lampiran 5

Untuk membuktikan hipotesis yang pertama yaitu diduga ada pengaruh secara bersama-sama alasan pemberhentian yang terdiri dari keinginan perusahaan dan keinginan karyawan terhadap semangat kerja karyawan PT. Jakarta Ponsel XXI Pamekasan peneliti menggunakan uji $\mathrm{F}$ yang hasil perhitungan dapat dilihat pada tabel 4.12.

Berdasarkan tabel 4.12 diatas dapat dijelaskan $F$ hitung sebesar 103,908 sedangkan $F$ tabel sebesar 3,40 didapat dengan tingkat signifikannya $\alpha=$ $5 \%$ kemudian menentukan df (derajat bebas) dimana df merupakan sekumpulan skor sampel yang bebas dari kesalahan. dengan jumlah variabel $(\mathrm{k})=2$ dan $\mathrm{n}=27$, maka $\mathrm{df}_{2}=\mathrm{n}-\mathrm{k}-1$ (27$2-1)=24$, jadi pada kolom ke 2 dan baris ke 24 yakni 3,40 (dapat dilihat pada lampiran tabel $\mathrm{F}$ ).
Dengan kriteria pengujian :

Jika $\mathrm{F}$ hitung $>\mathrm{F}$ tabel maka diterima dan

Jika $F$ hitung $<F$ tabel maka ditolak

Sehingga hipotesis pertama yaitu dugaan secara bersama-sama ada pengaruh alasan pemberhentian yang terdiri dari keinginan karyawan dan keinginan perusahaan terhadap semangat kerja karyawan PT. Jakarta Ponsel XXI Pamekasan benar atau diterima karena $\mathrm{F}$ hitung $>\mathrm{F}$ tabel atau $103,908>3,40$.

\section{b. Uji t}

Dengan menggunakan bantuan program Statistical Program for Social and Science (SPSS) versi 20 didapatkan hasil perhitungan Uji t pada tabel 4.13 dibawah ini :

Tabel 4.13

Hasil Perhitungan Uji $\mathrm{t}$

Hasil Perhitungan Uji t

\begin{tabular}{|c|c|c|}
\hline $\begin{array}{c}\text { Variabel Alasan } \\
\text { Pemberhentian }\end{array}$ & $\begin{array}{c}\text { Keinginan Perusahaan } \\
\left(\mathbf{X}_{\mathbf{1}}\right)\end{array}$ & $\begin{array}{c}\text { Keinginan Karyawan } \\
\left(\mathbf{X}_{\mathbf{2}}\right)\end{array}$ \\
\hline t hitung & 12,23 & 0,786 \\
\hline
\end{tabular}

Sumber : data diolah

Untuk membuktikan hipotesis yang kedua yaitu diduga keinginan perusahaan adalah variabel yang paling dominan mempengaruhi semangat kerja karyawan PT. Jakarta Ponsel XXI Pamekasan peneliti menggunakan uji $t$ yang hasil perhitungan dapat dilihat pada tabel 4.13.

Berdasarkan tabel 4.13 diatas dapat dijelaskan t hitung untuk variabel alasan pemberhentian yang terdiri dari keinginan perusahaan sebesar 12,23 dan keinginan karyawan sebesar 0,786 dibandingkan dengan $t$ tabel sedangkan untuk mencari nilai $t$ tabel dengan menggunakan derajad kebebasan sesuai banyaknya responden yang dijadikan sampel penelitian yaitu 27 orang, dan didapat nilai t tabel dari 27 orang pada tabel $\mathrm{t}$ (lihat lampiran tabel $\mathrm{t}$ ) sebesar 2,052 .

Sehingga jika $t$ hitung dibandingkan dengan $t$ tabel dari masing-masing variabel yaitu $t$ hitung keinginan perusahaan $\left(X_{1}\right)>t$ tabel $=$ $12,23>2,052$ dan $t$ hitung keinginan karyawan $\left(\mathrm{X}_{2}\right)<\mathrm{t}$ tabel $=0,786<2,052$. Dari hasil perbandingan nilai t hitung dan $t$ tabel dapat diketahui bahwa variabel keinginan perusahaan $\left(X_{1}\right)$ memiliki nilai $t$ hitung paling tinggi dari pada variabel keinginan karyawan $\left(X_{2}\right)$ sedangkan untuk menentukan variabel yang paling 
dominan adalah nilai t hitung yang paling tinggi.

Dari penjelasan diatas maka dapat disimpulkan bahwa hipotesis yang kedua yang menyatakan keinginan perusahaan $\left(X_{1}\right)$ adalah variabel yang paling dominan mempengaruhi semangat kerja karyawan PT. Jakarta Ponsel XXI Pamekasan benar dan dapat dibuktikan atau diterima.

\section{KESIMPULAN DAN SARAN}

\subsection{Kesimpulan}

Berdasarkan hasil analisis data dan pembahasan diatas, maka peneliti mengambil beberapa kesimpulan diantaranya :

1. Berdasarkan hasil analisa regresi linier berganda dari variabel keinginan perusahaan dan keinginan karyawan yang masing-masing memiliki nilai 1,033 dan 0,057 menunjukkan adanya hubungan searah terhadap semangat kerja karyawan PT. Jakarta Ponsel XXI Pamekasan.

2. Dari koefisien korelasi dan koefisien determinan pada penelitian ini antara keingian perusahaan dan keinginan karyawan terhadap semangat kerja karyawan PT. Jakarta Ponsel XXI Pamekasan terdapat hubungan yang sangat kuat yaitu sebesar 0,947.

3. Dari hasil Uji $F$ sebagai hipotesis yang pertama secara bersama-sama keinginan perusahaan $\left(X_{1}\right)$ dan keinginan karyawan $\left(\mathrm{X}_{2}\right)$ berpengaruh nyata terhadap semangat kerja karyawan PT. Jakarta Ponsel XXI Pamekasan sebesar 103,908.

4. Dari hasil Uji $t$ atau secara parsial keinginan perusahaan $\left(X_{1}\right)$ merupakan pengaruh yang paling dominan terhadap semangat kerja karyawan PT. Jakarta Ponsel XXI Pamekasan yaitu sebesar 12,23.

\subsection{Saran}

Berdasarkan pertimbangan diatas maka saran yang dapat diajukan peneliti adalah :
1. Ada faktor lain selain alasan pemberhentian yang terdiri dari keinginan perusahaan dan keinginan karyawan yang mempengaruhi terhadap semangat kerja karyawan PT. Jakarta Ponsel XXI Pamekasan yang harus dikaji oleh pihak perusahaan terutama pimpinan PT. Jakarta Ponsel XXI Pamekasan.

2. Berdasarkan hasil perhitungan dengan regresi linier berganda yang semuanya positif atau searah memiliki arti bahwa faktor-faktor tersebut akan dapat meningkatkan semangat kerja karyawan PT. Jakarta Ponsel XXI Pamekasan.

3. Peneliti menyarankan agar peneliti selanjutnya dapat mengkaji hal-hal lain yang belum ada atau masih kurang dalam penelitian ini baik dari segi variabel independen maupun variabel dependen.

\section{DAFTAR PUSTAKA}

Hasibuan, Malayu S.P. 2013.

Manajemen Sumber Daya

Manusia; Bumi Aksara, Jakarta.

Sani S, Achmad dan Machfudz, Masyhuri. 2010. Metodologi Riset Manajemen Sumberdaya Manusia; UIN-MALIKI PRESS, Malang.

Santoso, Singgih. 2000. Buku Latihan SPSS Statistik Parametrik Edisi 1; PT. Elek Media Komputindo, Jakarta.

Sedarmayanti. 2007. Manajemen

Sumber Daya Manusia

Reformasi Birokrasi Dan

Manajemen Pegawai Negeri

Sipil, Bandung.

\section{Sugiyono. 2001. Metodologi Penelitian}

Administrasi. Cetakan

Kesembilan; Alfa Beta,

Bandung.

2004. Statistika Untuk

Penelitian. Cetakan Keenam;

Penerbit Alfabeta, Bandung. 
--------. 2009. Metode Penelitian

Kuantitatif, Kualitatif dan R \&

D; Penerbit Alfabeta, Bandung.

2011. Metode Penelitian

Kuantitatif Kualitatif dan R\&D;

Penerbit Alfabeta, Bandung.

Undang-Undang Republik Indonesia

Nomor 12 Tahun 1964 tentang

Pemutusan Hubungan Kerja Di

Perusahaan Swasta.

Undang-Undang Republik Indonesia

Nomor 25 Tahun 1997 tentang

Ketenaga Kerjaan.

Undang-Undang Republik Indonesia

Nomor 13 Tahun 2003 tentang

Ketenaga Kerjaan.

Sumber Internet:

Burhanuddin (1994.

http://tugasakhiramik.blogspot.c

o.id/2013/03/pengertian-

Dressler (2001.

semangat-kerja.html).

http://tugasakhiramik.blogspot.c o.id/2013/03/pengertian-

semangat-kerja.html).

Manullang (2005.

http://tugasakhiramik.blogspot.c o.id/2013/03/pengertiansemangat-kerja.html).

Prihanto

(http://davinplus.blogspot.co.id/2

012/07/cara-uji-reliabilitas-

instrumen-angket.html)

( http://www.putra-putri-

indonesia.com/alasan-phk.html)

(http://www.teruskan.com/24704/7-

penyebab-dan-alasan-

karyawan-berhenti-bekerja.html) 